\title{
Screening and molecular identification of hypercellulase and xylanase-producing microorganisms for bioethanol production
}

\author{
Nivedita Sharma* and Nisha Sharma \\ Microbiology Laboratory, Department of Basic Sciences, Dr Y. S. Parmar University of Horticulture and Forestry, Nauni-Solan 173230 , India
}

\begin{abstract}
The present study projects the baseline work for bioconversion of pine needles to second generation biofuel, which deals mainly with screening, molecular identification and optimization of process parameters for cellulase and xylanase production. In total, 89 hydrolytic enzymes producing isolates were isolated from the soils and ten potential enzyme producers (seven for cellulase and three for xylanase) were subjected to secondary screening by inducing physical and chemical mutation. The wild and mutant strains of hypercellulase producers $\mathrm{N}_{12}$ and $K \mathrm{~d}_{1}$ were identified as Bacillus stratosphericus $\mathrm{N}_{12}$ and Bacillus altitudinis $\mathrm{Kd}_{1}$ using $16 \mathrm{~S}$ rRNA technique. The fungal isolates RF1 and F2 were identified on the basis of 5.8 rRNA ITS technique and identified as Rhizopus oryzae, RF1 and Rhizopus delemar, F2 respectively. The mutant strains $B$. stratosphericus $\mathrm{N}_{12}(\mathrm{M})$ and $B$. altitudinis $\mathrm{Kd}_{1}(\mathrm{M})$ are highly stable till 10 generations. Cellulase activity increased from 3.230 to 5.983 IU, i.e. $85.23 \%$ increase in cellulase activity was achieved. Xylanase production increased from 51.32 to 95.25 IU with $85.60 \%$ increase in production. Solid-state fermentation was also performed by potential fungal strains, i.e. $R$. delemar F2 and $R$. oryzae RF1 using pine needles as the substrate.
\end{abstract}

Keywords: Bioethanol, cellulase, solid-state fermentation, submerged fermentation, xylanase.

\section{Introduction}

THE second-generation biofuel, i.e. bioethanol has become the most promising alternative substitute for gasoline and lignocelluloses have great potential as a biomass source for bioethanol production. Lignocellulosic materials such as agricultural residues, forestry residues like pine needles and woody biomass are regarded as potential long-term alternative feedstocks for bioethanol production, since they are the most abundant reproducible resource on the earth ${ }^{1}$. Microorganisms play a vital role in the conversion of lignocellulosic wastes into valuable products like biofuel. Successful bioconversion of cellu-

*For correspondence. (e-mail: niveditashaarma@yahoo.co.in) losic materials mainly depends on the nature of cellulose, sources of cellulolytic enzyme and optimal conditions for catalytic activity and production of enzymes ${ }^{2}$. Efficiency of hydrolytic enzyme is one of the determining factors for the saccharification of biomass into reducing sugars for bioethanol production. Thus employing efficient microbes that can produce both cellulase and xylanase may help overcome the current challenges in bioethanol production $^{3}$. Biodiversity of microorganisms in tropical forests offers greater possibility for obtaining potential microbes for this purpose. To enhance the efficiency of a strain mutation is a promising step in which changes can be observed in the nucleotide sequence of the genetic material of an organism. For strain improvement ultraviolet (UV) radiation, ethidium bromide, N-methyl-N-nitro-Nnitrosoguanidine (NTG) and sodium azide were used as potential mutagenic agents ${ }^{4}$. Attention towards hydrolytic enzymes production has consistently increased over the years, due to their potential use in several industries ${ }^{5}$. These enzymes have various applications such as in the clarification of juices, wine industry, poultry diet, animal feed and biofuel production. Biotechnological conversion of pine needles is a potentially sustainable approach to develop novel bioprocesses and products. Pine needles are a renewable and abundant resource with great potential for bioconversion to value-added bioproducts. Microbial enzymes have become the focal biocatalysts due to their complex nature and widespread industrial applications. So significant attention has been devoted to the current knowledge of enzyme production and the challenges in research, especially in the direction of improving the production process economically of various industries. The present study was aimed to screen hypercellulolytic and xylanolytic microorganisms and generate efficient hyper enzyme producers as well as highly stable mutant strains for hydrolytic enzyme production. In our previous studies, a total of 89 microorganisms, including 84 bacteria and five fungi were isolated from soil samples collected from different sites of Himachal Pradesh, India ${ }^{6}$. Among them, ten hypercellulase and xylanaseproducing bacteria were subjected to mutation for enhanced enzyme production and two highly stable mutant strains, i.e. $\mathrm{N}_{12}(\mathrm{M})$ and $\mathrm{Kd}_{1}(\mathrm{M})$ were screened for enhanced cellulase and xylanase enzyme production; 
different process parameters were optimized to further increase their enzyme activity.

\section{Materials and methods}

\section{Mutation of hypercellulolytic and xylanolytic bacteria for secondary screening}

The previously isolated bacteria from soil were subjected to primary screening and ten potential isolates were subjected to mutation for secondary screening.

(i) UV irradiation (physical mutation)

- UV light of laminar airflow (Phillips TUV $30 \mathrm{~W} /$ G30.T8), voltage: $30 \mathrm{~W}$, distance: $15 \mathrm{~cm}$ and time interval: $15,30,45,60$ and $75 \mathrm{~min}$.

(ii) Ethidium bromide (chemical mutation)

- Ethidium bromide (EtBr) concentration: 0.1-2.0 $\mathrm{mg} / \mathrm{ml}$

- Time interval: 30, 60, 90 and $120 \mathrm{~min}$.

\section{Molecular identification of screened hypercellulase and xylanase producers}

(i) $16 \mathrm{~S}$ rRNA technique

- Wild and mutant strains of $\mathrm{N}_{12}$ (hypercellulase producer) and $\mathrm{Kd}_{1}$ (hyperxylanase producer) were identified on the basis of 16S rRNA technique.

(ii) Clustal W2 analysis

- Translated nucleotide sequences were analysed for confirmation of mutation using website, i.e. www.ebi.ac.uk/services.

\section{Submerged fermentation}

Optimization of process parameters for cellulase and xylanase production by one-factor-at a time approach: Different process parameters were optimized for cellulase and xylanase production from mutant strains of Bacillus stratosphericus $\mathrm{N}_{12}(\mathrm{M})$ and Bacillus altitudinis $\mathrm{Kd}_{1}(\mathrm{M})$ under submerged $(\mathrm{SmF})$ fermentation.

Media optimization: Different media were used for enhanced cellulase and xylanase production.

Media used for cellulase production: PYC medium ${ }^{7}$, basal salt medium ${ }^{8}$, modified basal salt medium ${ }^{9}$, Okoshi et $a l .{ }^{10}$ medium, $\mathrm{Li}$ and $\mathrm{Gao}^{11}$ medium and Mandel and Reese medium ${ }^{12}$.

Media used for xylanase production: Bacillus xylose salt medium, xylan medium ${ }^{13}$, basal salt medium ${ }^{8}$, TGY medium $^{14}$, Emmerson medium $^{14}$, X. Heck medium ${ }^{15}$.
Temperature optimization: The temperature range $25^{\circ} \mathrm{C}$, $30^{\circ} \mathrm{C}, 35^{\circ} \mathrm{C}, 40^{\circ} \mathrm{C}, 45^{\circ} \mathrm{C}$ and $50^{\circ} \mathrm{C}$ was used for the study.

pH optimization: Different $\mathrm{pH}$ values ranging from 5.0, $5.5,6.0,6.5,7.0,7.5,8.0,8.5$ to 9.0 were used for optimization.

Effect of different inoculum sizes: Inoculum size ranging from $1.0 \%, 2.5 \%, 5.0 \%, 7.5 \%, 10.0 \%, 12.5 \%, 15.0 \%$ to $17.5 \%$ was used for optimization.

Effect of different carbon sources: Different substrates (hexoses) ranging from cellulose, mannose, dextrose, lactose, maltose to starch were used for optimization.

Optimization of concentration of best carbon source: Different concentrations of best carbon source were studied for their optimum concentration.

\section{Solid-state fermentation (SSF)}

Cellulase and xylanase production by $R$. oryzae $R F 1$ and R. delemar F2: (a) Collection of biomass: Pine needles were collected from the forests of Solan district and Shimla, Himachal Pradesh.

(b) Production and extraction of enzymes: To $5 \mathrm{~g}$ of each untreated and pretreated biomass, $10 \mathrm{ml}$ of moistening agent, viz. Vogel's medium was added (in the ratio $1: 6$, i.e. substrate : moistening agent) in a $250 \mathrm{ml}$ Erlenmeyer flask and autoclaved. Next, the flasks were inoculated with $2 \mathrm{ml} R$. oryzae $\mathrm{RF} 1$ and $R$. delemar $\mathrm{F} 2$ having $1 \times 10^{7}$ spores $/ \mathrm{ml}$ and incubated at $50^{\circ} \mathrm{C}$ for 7 days in static phase and extraction of the enzymes was done by Bollag and Edelstein extraction method ${ }^{16}$.

\section{Results and discussion}

\section{Mutation of hypercellulase and hyperxylanase- producing isolates for secondary screening}

In total, 84 bacterial isolates were obtained from soil samples in PYC (peptone yeast extract) medium having pH 6.8 and primarily screened on the basis of quantitative analysis of cellulase and xylanase under submerged fermentation. Seven bacterial isolates, i.e. $\mathrm{N}_{12}(1.476 \mathrm{IU})$, $\mathrm{S}_{12}(1.220 \mathrm{IU}), \mathrm{N}_{5}$ (1.503 IU), $\mathrm{S}_{7}(1.135 \mathrm{IU}), \mathrm{N}_{13}(2.138$ $\mathrm{IU}), \mathrm{NS}_{1}(1.689 \mathrm{IU})$ and $\mathrm{S}_{1}(1.639 \mathrm{IU})$ were selected for hypercellulase production on the basis of primary screening, whereas three bacterial isolates, i.e. $\mathrm{Kd}_{1}(31.72 \mathrm{IU})$, $\mathrm{SL}_{8}$ (61.54 IU) and $\mathrm{N}_{11}$ (29.64 IU) were selected for hyperxylanase production ${ }^{6}$. Two fungal isolates F2 and RF1 were also isolated from the soil and on the basis of their colour, texture and mycelia were tentatively identified as Rhizopus species. 

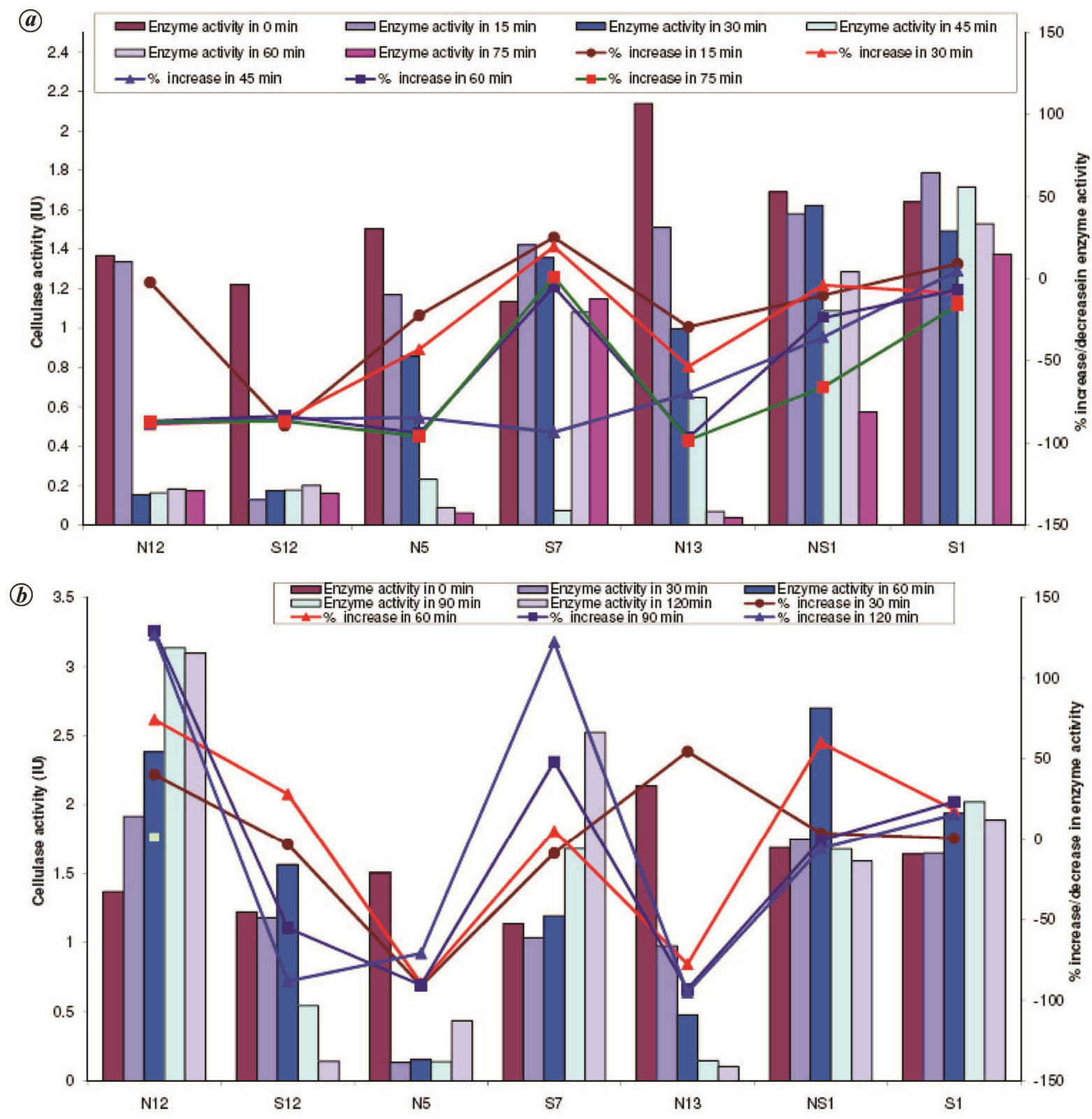

Figure 1. Overall comparison of per cent increase/decrease in cellulase activity of (a) UV-mutated and (b) EtBr-mutated strains over wild strains.

Secondary screening was done by subjecting these isolates to physical (UV radiation) and chemical mutation $(\mathrm{EtBr})$. Cellulase and xylanase production was done by selected isolates at different $\mathrm{UV}$ doses, i.e. $0.00012 \mathrm{~mJ} / \mathrm{cm}^{2}$ for $15 \mathrm{~min}, 0.00024 \mathrm{~mJ} / \mathrm{cm}^{2}$ for $30 \mathrm{~min}$, $0.00036 \mathrm{~mJ} / \mathrm{cm}^{2}$ for $45 \mathrm{~min}, 0.00048 \mathrm{~mJ} / \mathrm{cm}^{2}$ for $60 \mathrm{~min}$ and $0.00064 \mathrm{~mJ} / \mathrm{cm}^{2}$ for $75 \mathrm{~min}$ in PYC medium containing $0.5 \%$ cellulose for cellulase production and $0.5 \%$ xylan for xylanase production. Among different isolates $\mathrm{N}_{12}(\mathrm{M}), \mathrm{S}_{12}(\mathrm{M}), \mathrm{N}_{5}(\mathrm{M}), \mathrm{N}_{13}(\mathrm{M})$ and $\mathrm{NS}_{1}(\mathrm{M})$ showed a decrease, while $S_{7}(M)$ and $S_{1}(M)$ showed an increase in cellulase activity, i.e. from 1.135 to $1.421 \mathrm{IU}$ and 1.639 to $1.787 \mathrm{IU}$ respectively (Figure $1 a$ ). In case of xylanase production from UV-treated isolates $\mathrm{Kd}_{1}(\mathrm{M})$ and $\mathrm{N}_{11}(\mathrm{M})$ showed increase in xylanase activity ranging from 31.72 to $51.32 \mathrm{IU}$ and 29.05 to $31.30 \mathrm{IU}$ respectively, while isolate $\mathrm{SL}_{8}(\mathrm{M})$ showed a decrease in xylanase activity (Figure $1 b$ ). Based upon the results $\mathrm{Kd}_{1}(\mathrm{M}) \mathrm{UV}$ irradiated was selected for the optimization process. UV radiation have been considered important inducers for strain mutations. The pyrimidines are especially sensitive to modification by absorption of UV radiation which results in the production of thymine dimers that distort the DNA helix and block future replication ${ }^{17}$. In a similar study, Ghazi et al. ${ }^{18}$ produced a mutant strain of Bacillus mojavensis PTCC1723 by inducing UV mutation which gave 3.45 times higher xylanase than the parent strain. 

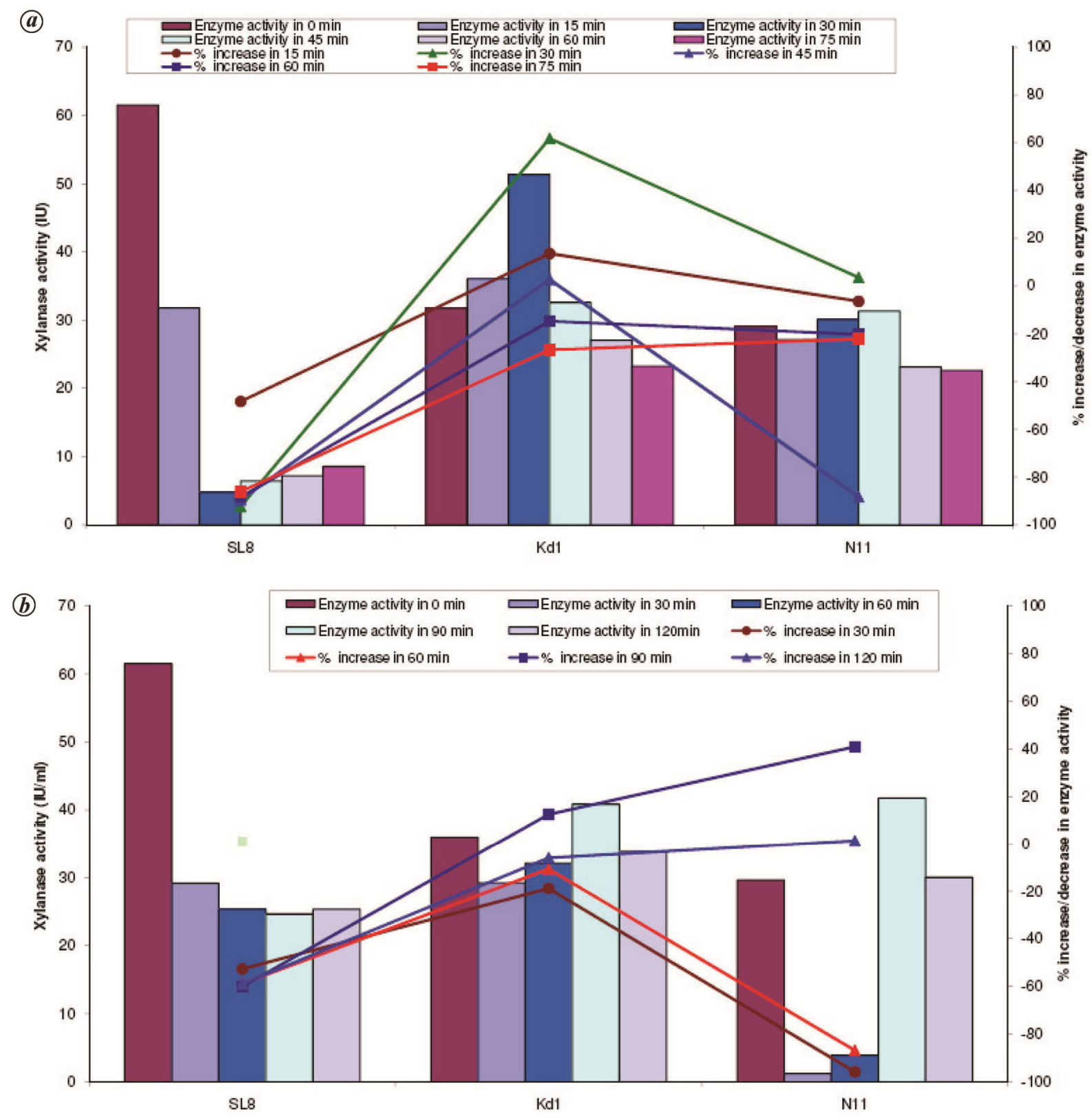

Figure 2. Overall comparison of per cent increase/decrease in xylanase activity of (a) UV-mutated and (b) EtBr-mutated strains over wild strains.

During EtBr mutation the isolate $\mathrm{N}_{12}(\mathrm{M})$ showed highest increase in cellulase activity with $\mathrm{EtBr}(90 \mathrm{~min}$ exposure), i.e. 1.367-3.136 IU (2.29-fold increase) and was selected for the optimization process (Figure $2 a$ ) and mutant $\mathrm{Kd}_{1}(\mathrm{M})$ produced $51.33 \mathrm{IU}$ (1.61-fold increase) of xylanase and $\mathrm{N}_{11}(\mathrm{M})$ showed $31.30 \mathrm{IU}$ (1.07-fold increase), while $\mathrm{SL}_{8}(\mathrm{M})$ showed a decrease in xylanase activity upon mutation (Figure $2 b$ ). Some of the isolates after mutation showed an escalation in enzyme units, while others declined compared to their respective wild strains. Figure $1 a$ and $b$ shows the overall per cent increase/decrease in cellulase activity when bacterial isolates were subjected to UV and EtBr. $\mathrm{N}_{12}(\mathrm{M})$ showed $129.40 \%$,
$\mathrm{S}_{12} 28.03 \%, \mathrm{~S}_{7} 122.37 \%, \mathrm{NS}_{1} 59.91 \%$ and $\mathrm{S}_{1} 23.24 \%$ increase in cellulase activity, while others showed a decrease with this treatment. On the other hand, in case of xylanase activity during mutation with $\mathrm{EtBr}$, isolate $\mathrm{Kd}_{1}(\mathrm{M})$ showed an increase of $13.50 \%$ and $\mathrm{N} 1140.89 \%$, while $\mathrm{SL}_{8}$ showed a decrease in xylanase activity (Figure 2).

In a study by Kuttanpillai et al. ${ }^{19}$, Thermomyces lanuginosus MC 134 mutant showed a 1.5 -fold increase in xylanase production on oat spelt xylan compared to wild strain. Finally, of $\mathrm{Kd}_{1}$ (UV-mutated) for xylanase production and $\mathrm{N}_{12}$ (EtBr-mutated) for cellulase production were selected for further experiments on the basis of highest enzymes secreted by them. 


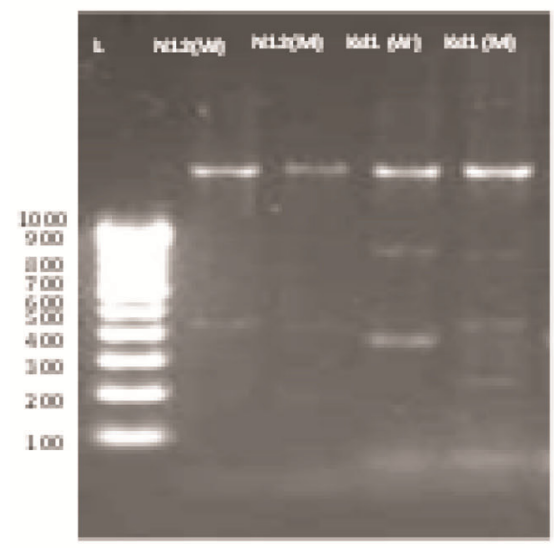

Genomic DNA

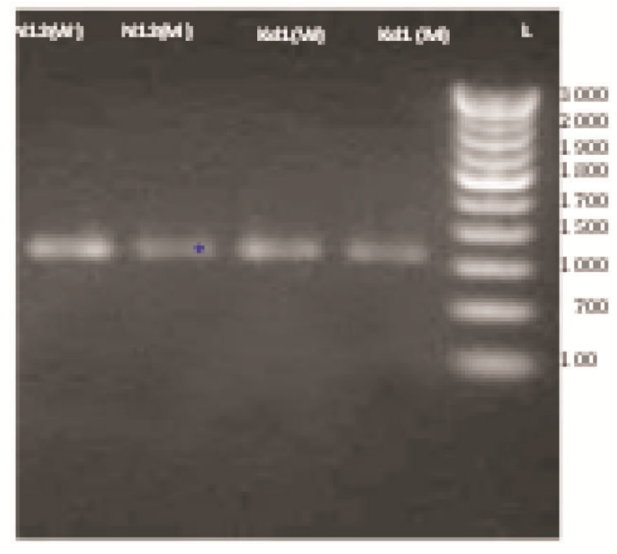

PCR product

Figure 3. Molecular identification of bacterial isolates Bacillus stratosphericus $\mathrm{N}_{12}(\mathrm{~W}), \mathrm{N}_{12}(\mathrm{M})$ and Bacillus altitudinis $\mathrm{Kd}_{1}(\mathrm{~W})$ and $\mathrm{Kd}_{1}(\mathrm{M})$ using $16 \mathrm{~S}$ rRNA gene technique.

(a)

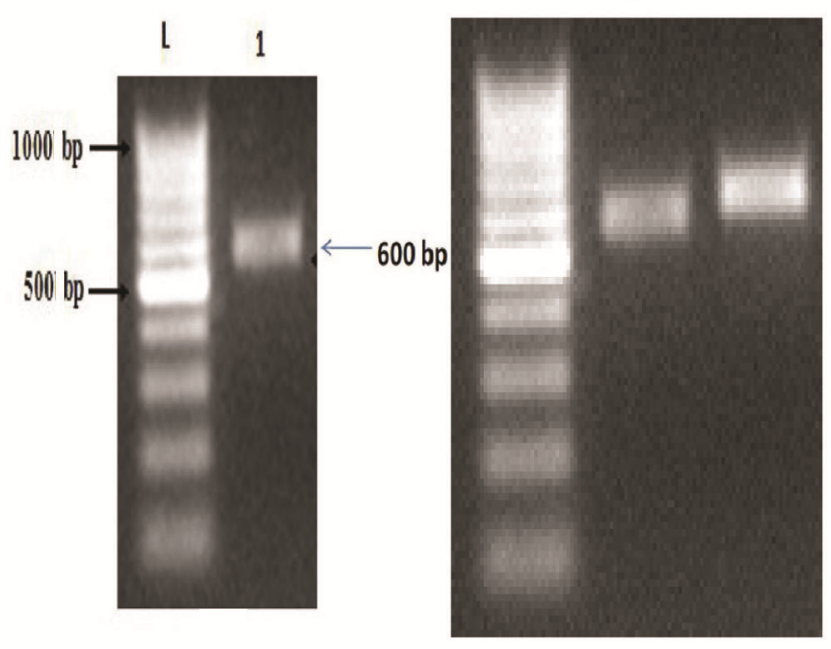

Figure 4. Molecular identification of screened fungal isolates (a) Rhizopus oryzae F2 and (b) Rhizopus delemar RF1 using ITS 5.8 rRNA gene technique.

\section{Molecular identification of screened hypercellulolytic and xylanolytic microorganisms}

Two bacterial strains with their respective mutants and two fungal strains were identified at genomic level using 16S rRNA gene and 5.8 rRNA ITS technique respectively. Genomic DNA of isolates was isolated using DNA purification kit (Banglore Genei). The sequences of these isolates have been registered under Genebank database with the following accession numbers: Bacillus stratosphericus $\mathrm{N}_{12}(\mathrm{~W})$ [KC995116], Bacillus stratosphericus $\mathrm{N}_{12}$ (M) [KC995118], Bacillus altitudinis $\mathrm{Kd}_{1}$ (W) [KC995115], Bacillus altitudinis $\mathrm{Kd}_{1}(\mathrm{M})$ [KC995117], Rhizopus oryzae RF1 [KJ192199] and Rhizopus delemar F2 [KX5123312]. Figures 3 and 4 present phylogenetic trees of the bacterial and fungal strains with respect to other related species as inferred by neighbour joining method. The 16S rRNA gene is used for phylogenetic studies because it is highly conserved between different species of bacteria and archea, and always yields confirmed identification. The 16S rRNA gene analysis has been adapted globally as it is an authenticated approach to identify different isolates and characterize their morphological and phylogenetic position ${ }^{20}$. A phylogenetic analysis based on 16S rRNA gene sequence comparisons revealed that strain JSM $081003 \mathrm{~T}$ should be assigned to the genus Bacillus, and was related most closely to the type strains of Bacillus lehensis (sequence similarity 99.6\%), Bacillus oshimensis (99.4\%) and Bacillus patagoniensis (96.6\%); lower than $96.0 \%$ sequence similarity was observed with other Bacillus species ${ }^{21}$.

\section{Optimization of cellulase and xylanase by potential microorganisms under submerged fermentation}

The data revealed that highest cellulase activity was found in the PYC (3.230 IU), while least enzyme production $(2.211 \mathrm{IU})$ was observed in Okoshi et al. ${ }^{10}$ medium. PYC medium containing carboxy-methyl cellulose $(1.0 \%)$, sodium chloride $(0.05 \%)$, yeast extract $(0.5 \%)$, potassium hydrogen phosphate $(0.3 \%)$, magnesium sulphate $(0.02 \%)$ and peptone $(0.5 \%)$ as growth supplements seems to have promoted extracellular cellulase production. Sodium chloride present in the medium probably helped maintain the osmotic balance of the medium while magnesium sulphate was a cofactor for a variety of metabolic reactions.

On the other hand strain B. altitudinis $\mathrm{Kd}_{1}(\mathrm{M})$ showed maximum activity (56.83 IU) in TGY medium. This medium supported highest production of xylanase in case of B. altitudinis $\mathrm{Kd}_{1}(\mathrm{M})$. Effect of glucose and tryptone 
added in the TGY medium seem to induced high titres of xylanase. Glucose present in medium must have served as a ready utilizable carbon source leading to higher growth of $B$. altitudinis $\mathrm{Kd}_{1}(\mathrm{M})$, consequently causing more synthesis of extracellular xylanase. Besides, tryptone used as nitrogen source, plays a significant role in promoting the extracellular release of enzymes. Thus medium formulation is a crucial step for designing successful laboratory experiments to enhance the yield of enzymes. It clearly reflects that medium components must satisfy the elemental requirement for cell biomass and enzyme production. A perusal of the data revealed that maximum production of cellulase was observed at $\mathrm{pH} 8.0$, i.e. $3.370 \mathrm{IU}$, which was significantly higher than others statistically and minimum was observed at $\mathrm{pH} 5.0$, i.e. $1.16 \mathrm{IU}$. The highest xylanase titres were observed at $\mathrm{pH}$ 5.5, i.e. $59.09 \mathrm{IU}$, followed by $58.72 \mathrm{IU}$ at $\mathrm{pH} 6.5$, which were also statistically significantly higher than others, and least xylanase titres were observed at $\mathrm{pH} 9.0$, i.e. $25.48 \mathrm{IU}$. Thus B. stratosphericus $\mathrm{N}_{12}(\mathrm{M})$ has emerged as an alkalophile showing highest enzyme production at $\mathrm{pH}$ 8.0. In contrast, $B$. altitudinis $\mathrm{Kd}_{1}(\mathrm{M})$ showed acidophilic nature by exhibiting maximum release of enzymes in the acidic range, i.e. 5.5. $\mathrm{pH}$ of the medium influences the growth of microorganisms and hence the enzyme production. Each microorganism possesses a specific $\mathrm{pH}$ range for its growth and activity. The extracellular $\mathrm{pH}$ has a strong influence on the pathways of metabolism and product formation by microorganism. Changes in the external $\mathrm{pH}$ alter the ionization of nutrient molecules and reduce their availability to the organism, thus lowering the overall metabolic activity ${ }^{22}$.

Maximum cellulase titres were produced at $30^{\circ} \mathrm{C}$ by $B$. stratosphericus $\mathrm{N}_{12}(\mathrm{M})$, i.e. (3.789 IU), whereas least cellulase production was found at $45^{\circ} \mathrm{C}$ (1.082 IU). Similarly, $B$. altitudinis $\mathrm{Kd}_{1}(\mathrm{M})$ also exhibited optimum temperature, i.e. $30^{\circ} \mathrm{C}(71.33 \mathrm{IU})$ for maximum xylanase production which is significantly higher than others. Temperature variation is a special feature because it can penetrate physical barrier and can have dramatic effects on the structure of macromolecules and also affect all the levels of biological adaptation ${ }^{23}$. Similar findings have been reported by Kumar et al. ${ }^{24}$ showed increased enzyme activity of $62 \mathrm{U} / \mathrm{ml}$ at $30^{\circ} \mathrm{C}$ and found it to be the optimum temperature for $\beta$-glucosidase production.

Effect of inoculum size on cellulase and xylanase production was evaluated using different inoculum sizes, i.e. $2.5 \%, 5.0 \%, 7.5 \%, 10.0 \%, 12.5 \%, 15.0 \%$ and $17.5 \%$ $(\mathrm{V} / \mathrm{V})$. The data revealed that optimum inoculum size was found to be $10.0 \%(\mathrm{~V} / \mathrm{V})$ for cellulase production showing $3.808 \mathrm{IU}$. Highest xylanase production from B. altitudinis $\mathrm{Kd}_{1}(\mathrm{M})$, i.e. $73.44 \mathrm{IU}$ was obtained at $12.5 \%$ of inoculum size having statistically significant differences over other inoculum sizes. The least cellulase and xylanase units were recorded at $15.0 \%$. Enzyme activity was maximum at optimal level because at this point equili- brium is maintained between inoculum size and availability of substrates, while the decline in enzyme yield at larger inoculum size might be due to formation of thick suspensions and improper mixing of substrates in shake flasks. Singh and Kaur ${ }^{25}$ reported that maximum inoculum size of $10 \%$ could be used for cellulase production from Bacillus sp. JS14 under SSF.

Enzyme activity was measured at regular intervals up to periods of 24 to $120 \mathrm{~h}$. Highest cellulase activity was measured at $48 \mathrm{~h}$ (4.259 IU) from B. stratosphericus $\mathrm{N}_{12}$ (M). Least enzyme production was observed at $24 \mathrm{~h}$ (2.34 IU) of fermentation. Statistically, enzyme production was found significantly higher at $48 \mathrm{~h}$ than other timings. In case of xylanase, the production was found minimum at $24 \mathrm{~h}$ of fermentation by $B$. altitudinis $\mathrm{Kd}_{1}(\mathrm{M})$, i.e. $53.51 \mathrm{IU}$, while maximum xylanase production was noticed at $48 \mathrm{~h}$, i.e. $74.45 \mathrm{IU}$. Shanmugapriya et al. ${ }^{26}$ optimized the culture conditions for cellulase production by Bacillus sp. and observed maximum enzyme production at $48 \mathrm{~h}$ of incubation, $\mathrm{pH} 6.0$ and temperature of $40^{\circ} \mathrm{C}$. Nirmala and $\operatorname{Sindhu}^{27}$ recorded maximum cellulase production from Bacillus strain at $72 \mathrm{~h}(5.0 \mathrm{IU} / \mathrm{ml})$ of fermentation time. Shankar and Isaiarasu ${ }^{28}$ reported maximum cellulase production at $72 \mathrm{~h} \quad(0.5851 \pm$ $0.006 \mathrm{IU} / \mathrm{ml}$ ) from Bacillus pumilus EWBCM1 under varying cultural conditions.

The effect of different carbon source, i.e. cellulose, mannose, dextrose, lactose, maltose and starch for cellulase production as well as xylose, maltose, xylan, arabinose, ribose and dextrose for xylanase production were studied. Statistical analysis showed significant variation among all the substrates for enzyme titres. The cellulase units varied from 3.130 to $5.515 \mathrm{IU}$ in $B$. stratosphericus $\mathrm{N}_{12}$ (M), whereas xylanase titre varied from 18.55 to $75.16 \mathrm{IU}$ in B. altitudinis $\mathrm{Kd}_{1}(\mathrm{M})$. Optimal level of cellulase was recorded when lactose was used as a carbon source, while maximum xylanase was produced using xylose as carbon source. The mechanism of lactose induction is considered to be due to the intracellular galactose-1-phosphate levels which are responsible for controlling the signalling of cellulase production ${ }^{29}$. Cellulase is an inducible enzyme which is induced in the presence of soluble saccharides. Lactose has been found as a suitable inducer of cellulase enzyme compared to other carbon sources, viz. glucose, sucrose, fructose and galac$\operatorname{tose}^{30}$. Gupta and $\mathrm{Kar}^{31}$ reported stimulation of xylanase production by xylose from thermophillic Bacillus sp. under submerged fermentation. Kapoor et al. ${ }^{32}$ observed maximum xylanase production from Bacillus pumilus MK001 in a medium containing xylose as carbon source. There was significant variation among different substrate concentrations used for cellulase production ranging from $0.5 \%$ to $3.0 \%$ from hypercellulolytic B. stratosphericus $\mathrm{N}_{12}$ (M), and for xylanase production from hyperxylanolytic $B$. altitudinis $\mathrm{Kd}_{1}(\mathrm{M})$. Optimum level of substrate concentration was found @2.0\% for B. stratosphericus 
Table 1. Hydrolytic enzymes (cellulase and xylanase) production under solid-state fermentation by $R$. oryzae RF1

\begin{tabular}{lcccccrc}
\hline Biomass & $\begin{array}{c}\text { Total cellulase } \\
\text { (IU) }\end{array}$ & $\begin{array}{c}\text { Cellulase } \\
(\mathrm{U} / \mathrm{g})\end{array}$ & $\begin{array}{c}\text { Protein } \\
(\mathrm{mg} / \mathrm{g})\end{array}$ & $\begin{array}{c}\text { Specific } \\
\text { activity }\end{array}$ & $\begin{array}{c}\text { Xylanase } \\
(\mathrm{IU})\end{array}$ & $\begin{array}{c}\text { Xylanase } \\
(\mathrm{U} / \mathrm{g})\end{array}$ & $\begin{array}{c}\text { Specific } \\
\text { activity }\end{array}$ \\
\hline Untreated & 0.539 & 5.39 & 7.06 & 0.763 & 9.12 & 91.20 & 12.91 \\
Microwave pretreated & 0.913 & 9.13 & 7.75 & 1.178 & 21.90 & 219.00 & 28.25 \\
\hline
\end{tabular}

Table 2. Hydrolytic enzymes (cellulase and xylanase) production under solid-state fermentation by Rhizopus delemar F2

\begin{tabular}{|c|c|c|c|c|c|c|c|}
\hline Biomass & $\begin{array}{c}\text { Total cellulase } \\
\text { (IU) }\end{array}$ & $\begin{array}{l}\text { Cellulase } \\
(\mathrm{U} / \mathrm{g})\end{array}$ & $\begin{array}{l}\text { Protein } \\
(\mathrm{mg} / \mathrm{g})\end{array}$ & $\begin{array}{l}\text { Specific } \\
\text { activity }\end{array}$ & $\begin{array}{l}\text { Xylanase } \\
\text { (IU) }\end{array}$ & $\begin{array}{l}\text { Xylanase } \\
(\mathrm{U} / \mathrm{g})\end{array}$ & $\begin{array}{l}\text { Specific } \\
\text { activity }\end{array}$ \\
\hline Untreated & 0.472 & 4.72 & 6.09 & 0.775 & 7.10 & 71.00 & 11.65 \\
\hline Microwave pretreated & 0.801 & 8.01 & 7.06 & 1.134 & 14.99 & 149.90 & 21.10 \\
\hline
\end{tabular}

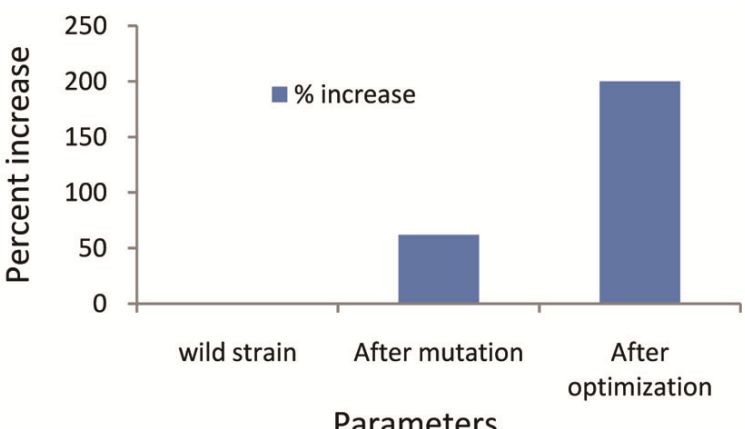

Figure 5. An overview of per cent increase in cellulase activity of $B$. stratosphericus $\mathrm{N}_{12}(\mathrm{M})$ after optimization of different parameters under SmF.

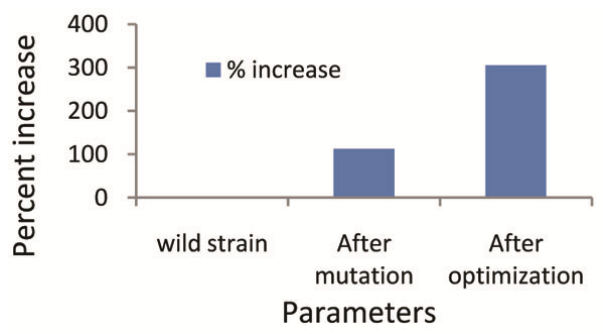

Figure 6. An overview of per cent increase in xylanase activity of wild $B$. altitudinis $\mathrm{Kd}_{1}(\mathrm{M})$ after mutation and optimization of different parameters under SmF.

$\mathrm{N}_{12}$ (M) showing significantly higher cellulase activity of $5.983 \mathrm{IU}$, whereas least enzyme activity (3.358 IU) was recorded in $0.5 \%$ substrate concentration. The effect of substrate concentration on xylanase production from potential bacteria revealed that $B$. altitudinis $\operatorname{Kd}_{1}(\mathrm{M})$ exhibited higher statistically significant xylanase activity at $2.5 \%$ substrate concentration, i.e. 95.25 IU. Minimum xylanase production, i.e. $52.60 \mathrm{IU}$ was observed at $0.5 \%$ substrate concentration for this hyperxylanolytic bacteria. Figures 5 and 6 show overall per cent increase after mutation as well as optimization of different process parame- ters, i.e. media, $\mathrm{pH}$, temperature, inoculum size, incubation time, carbon source and different concentrations of carbon source. Cellulase activity increased from 3.230 to $5.983 \mathrm{IU}$, i.e. 1.85 -fold (Figure 5). With regard to per cent increase, 200.00 in cellulase activity and 305.35 increase in xylanase activity was achieved (Figure 6). Classical approach of one factor at a time (OFAT) used in the present enzyme optimization study has resulted in an impressive increase in the production of cellulase as well as xylanase, thus proving the direct utility of this technique in increasing enzyme titres. 


\section{Hydrolytic enzymes production under solid state fermentation}

SSF involves the cultivation of microorganisms on a solid substrate in the near absence of free-flowing liquid. The characteristics of filamentous fungi, most notably hyphal growth, tolerance of low water activity, protein secretion and the ability to grow on a variety of low-value lignocellulosic materials provide a unique adaptability for fungi to SSF mode. In the present study, SSF was performed by $R$. oryzae and $R$. delemar using microwave pretreated pine needles biomass. Tables 1 and 2 depict cellulase and xylanase production under SSF, with maximum production using microwave pretreated biomass over untreated biomass. $R$. oryzae produced highest cellulase $(9.13 \mathrm{U} / \mathrm{g})$ and xylanase $(21.90 \mathrm{U} / \mathrm{g})$ using pretreated biomass, while $R$. delemar produced cellulase of $8.01 \mathrm{U} / \mathrm{g}$ and xylanase of $14.99 \mathrm{U} / \mathrm{g}$. The moisture involved in the SSF process facilitates the growth and metabolic functions of the microorganisms that are typically retained within the growth matrix. The characteristics of filamentous fungi, most notably hyphal growth, tolerance of low water activity, protein secretion and the ability to grow on a variety of low-value lignocellulosic materials provide a unique adaptability for moulds to SSF mode.

\section{Conclusion}

The present study was carried out to isolate, screen and identify the most efficient cellulolytic and xylanolytic microorganisms from the soil. Mutation of hypercellulase and xylanase producers, enzyme production and optimization were performed with selected strains to recommend their use for industries. The bacterial isolates were screened for hypercellulase and xylanase production by inducing mutation with UV radiation/ethidium bromide with an apparent aim to enhance enzyme production. Two new mutant strains, i.e. $\mathrm{N}_{12}(\mathrm{M})$ and $\mathrm{Kd}_{1}(\mathrm{M})$ were generated which were highly stable from ten generations and exhibited appreciable increase after mutation (1.476$3.136 \mathrm{IU}$ in cellulase and $31.72-51.32 \mathrm{IU}$ in xylanase production respectively). They were identified as $B$. stratosphericus $\mathrm{N}_{12}(\mathrm{M})$ and $B$. altitudinis $\mathrm{Kd}_{1}(\mathrm{M})$. Optimization of different process parameters for cellulase and xylanase production for mutant strains, $B$. stratosphericus $\mathrm{N}_{12}(\mathrm{M})$ and $B$. altitudinis $\mathrm{Kd}_{1}(\mathrm{M})$ using OFAT approach helped achieve $200.00 \%$ and $305.35 \%$ increase in their activities respectively. Basic and applied research on microbial cellulases and xylanases generated great scientific knowledge about their enormous industrial applications. To fulfill the requirement of enzymes on the industriallevel hyper enzyme producer strains are required. The present study provides a glimpse of the dynamics of cellulase and xylanase for their enhanced production from newly generated mutant strains. There hydrolytic enzymes can be further used for the conversion of pine needles to fermentable sugars, which is a feasible process and offers potential to reduce the use of fossil fuels as well as environmental pollution.

1. Keshwani, D. R., Modeling changes in biomass composition during microwave based alkali preteatment of switchgrass. Biotechnol. Bioeng., 2010, 105, 88-97.

2. Lynd, L. R., Weimer, P. J., van Zyl, W. H. and Pretorius, I. S., Microbial cellulose utilization: fundamentals and biotechnology. Microbiol. Mol. Biol. Rev., 2002, 66, 506-577.

3. Alam, M. Z., Manchur, M. A. and Anwar, M. N., Isolation, purification, characterization of cellulolytic enzymes produced by the isolate Streptomyces omiyaensis. Pak. J. Biol. Sci., 2004, 7, 1647 1653.

4. Sharma, V. and Singh, P. K., Strain improvement of Bacillus coagulans and Geobacillus stearothermophilus for enhanced thermostable cellulase production and the effect of different metal ions on cellulase activity. Int. J. Eng. Sci. Technol., 2012, 4, 47044709 .

5. Immanuel, G., Dhanusha, R., Prema, P. and Palavesam, A., Effect of different growth parameters on endoglucanase enzyme activity by bacteria isolated from coir retting effluents of estuarine environment. Int. J. Environ. Sci. Technol., 2006, 3, 25-34.

6. Sharma, N. and Sharma, N., Cellulase and xylanase productions from cellulolytic and xylanolytic microorganisms isolated from soils of Northern Himalayas. World J. Pharm. Res., 2016, 5, 754764.

7. Kim, J., Hur, S. and Hong, J., Purification and characterization of alkaline cellulase from a newly isolated alkalophilic Bacillus sp. HSH-810. Biotechnol. Lett., 2005, 27, 313-316.

8. Maniatis, T., Fritsch, E. F. and Sambrock, J., Molecular Cloning: A Laboratory Manual, Cold Spring Harbour Laboratory, New York, USA, 1982.

9. Sharma, N., Bansal, K. L. and Neopaney, B., Comparison of forest waste degradation under solid state fermentation and submerged fermentation by co-culture of Bacillus coagulans and Bacillus licheniformis. Asian J. Microbiol. Biotechnol. Environ. Sci., 2005, 7, 51-54.

10. Okoshi, H., Ozaki, K., Shikate, S., Oshoni Kawai, S. and Ito, S., Purification and characterization of multiple carboxymethyl cellulases from Bacillus sp. KSM-522. Agric. Biol. Chem., 1990, 54, 83-89.

11. Li, X. and Gao, P., CMC-liquefying enzyme, a low molecular mass initial cellulose-decomposing cellulase responsible for fragmentation from Streptomyces sp. LX. Appl. Microbiol., 1997, 83, 59-66.

12. Vyas, A., Vyas, D. and Vyas, K. M., Production and optimization of cellulases on pretreated groundnut shell by Aspergillus terreus AV49. J. Sci. Ind. Res., 2005, 64, 281-286.

13. Annamalai, N., Thavasi, R., Jayalakshmi, S. and Balasubramanium, T., Thermostable and alkaline tolerant xylanase production by Bacillus subtilis isolated from marine environment. Indian J. Biotechnol., 2009, 8, 291-297.

14. Garg, S., Ali, R. and Kumar, A., Production of alkaline xylanase by an alkalo-thermophilic bacteria, Bacillus halodurans, MTCC9512 isolated from dung. Curr. Trends Biotechnol. Pharm., 2009, 3, 90-96.

15. Heck, J. X., Hertz, P. F. and Ayub, M. A. Z., Cellulase and xylanase production by isolated amazon Bacillus strains using soyabean industrial residue based solid state cultivation. Braz. J. Microbiol., 2002, 33, 213-218.

16. Bollag, D. M. and Edelstein, S. J., Protein Methods, Wiley Liss, John Wiley, New York, USA, 1993. 
17. Chavan, A., Chougale, D., Lakshmikantha, R. Y. and Satwadi, S. P. R, Mutational study of Bacillus species for production, purification and characterization of lipase. Int. J. Pharm. Chem. Biol. Sci., 2012, 2, 545-551.

18. Ghazi, S., Sepahy, A.A., Azin, M., Khaje, K. and Khavarinejad, R., UV mutagenesis for the overproduction of xylanase from $\mathrm{Ba}$ cillus mojavensis PTCC1723 and optimization of the production condition. Iran. J. Basic Med. Sci., 2014, 17, 844-853.

19. Kuttanpillai, S. K., Permaul, K. and Singh, S., Inducible character of $\beta$-xylanase in a hyperproducing mutant of Thermomyces lanuginosus. Eng. Life Sci., 2009, 9, 298-230.

20. Fontana, C. M., Favaro, M., Pelliccioni, E. S. and Favalli, P. C., Use of the Microseq 16S rRNA gene-based sequencing for identification of bacterial isolates that commercial automated systems failed to identify correctly. J. Clin. Microbiol., 2005, 43, 615-619.

21. Chen, J., Zhang, L., Zhan, P., Wang, Y., Ai, B and Wang, G., Optimization of simultaneous saccharification and co-fermentation process for ethanol production from poplar wood. In International Conference Agricultural and Biosystems Engineering, Hong Kong, 2011, vol. 1, pp. 291-294.

22. Willey, J. M., Sherwood, L. M. and Woolverton, C. J., Prescott, Harley and Kleins' Microbiology, McGraw Hill, Boston, USA, 2008, 7 th edn.

23. Hickey, D. A. and Singer, G. A., Genomic and proteomics adaptation to growth at high temperature. Genome Biol., 2004, 5, 1-7.

24. Kumar, D. J. M., Sudha, M., Devika, S., Balakumaran, M. D., Kumar, M. R. and Kalaichelvan, P. T., Production and optimization of $\beta$-glucosidase by Bacillus sp. MPTK 121 , isolated from dairy plant soil. Ann. Biol. Res., 2012, 3, 1712-1718.

25. Singh, J. and Kaur, P., Optimization of process parameters for cellulase production from Bacillus sp. JS14 in solid substrate fermentation using response surface methodology. Braz. Arch. Biol. Technol., 2012, 55, 505-512.

26. Shanmugapriya, K., Saravana, P. S., Krishnapriya, Manoharan, M., Mythili, A. and Joseph, S., Isolation, screening and partial purification of cellulase from cellulase producing bacteria. Int. $J$ Adv. Biotechnol. Res., 2012, 3, 509-514.

27. Nirmla, P. and Sindhu, A., Production of endoglucanase by optimizing the environmental conditions of Bacillus circulans on submerged fermentation. Int. J. Appl. Eng. Res., 2011, 2, 472-481.

28. Shankar, T. and Isaiarasu, L., Cellulase production by Bacillus pumilus EWBCM1 under varying conditions. Middle East J. Sci. Res., 2011, 8, 40-45.

29. Seiboth, B., Gamauf, C., Pail, M., Hartl, L. and Kubicek, C. P., The D-xylose reductase of Hypocrea jecorina is the major aldose reductase in pentose and D-galactose catabolism and necessary for beta-galactosidase and cellulase induction by lactose. Mol. Microbiol., 2007, 66, 890-900.

30. Sadhu, S., Saha, P., Sen, S. K., Mayilraj, S. and Maiti, T. K., Production, purification and characterization of a novel thermotolerant endoglucanase (CMCase) from Bacillus strain isolated from cow dung. Springer Plus, 2013, 2, 1-10.

31. Gupta, U. and Kar, R., Optimization and scale up of cellulase free endo-xylanase production by solid state fermentation on corn cob and by immobilized cells of a thermolerant bacterial isolates. Jordan J. Biol. Sci., 2008, 1, 129-134.

32. Kapoor, M., Lavanya, M. N. and Kuhad, R. C., Cost effective xylanase production from free and immobilized Bacillus pumilus strain MK001 and its application in saccharification of Prosopis juliflora. Biochem. Eng. J., 2008, 38, 88-97.

ACKNOWLEDGEMENTS. We thank the National Mission on Himalayan Studies, Ministry of Environment, Forest and Climate Change, Government of India and G.B. Pant National Institute of Himalayan Environment and Sustainable Development, Almora for financial support.

doi: $10.18520 / \mathrm{cs} / \mathrm{v} 120 / \mathrm{i} 5 / 841-849$ 